\title{
Nutritional parameters of lambs fed extruded ration with different roughage to concentrate ratios
}

\section{Parâmetros nutricionais de cordeiros alimentados com ração extrusada em diferentes relações volumoso: concentrado}

\author{
Karla Alves Oliveira ${ }^{1 *}$; Gilberto de Lima Macedo Júnior ${ }^{2}$; Laura Ferrari Monteiro \\ Varanis $^{3}$; Carolina Moreira Araújo ${ }^{1}$; Tamires Soares de Assis ${ }^{1}$; Marco Túlio Santos \\ Siqueira $^{4}$; Luciano Fernandes Sousa ${ }^{5}$
}

\begin{abstract}
The objective of our study was to compare the intake and digestibility of dry matter and nutrients, and the nitrogen balance, of lambs fed extruded ration with different roughage (R) to concentrate (C) ratios. The experiment was carried out at the Federal University of Uberlândia (UFU), Experimental Farm Capim Branco, from 7 December 2016 to 6 January 2017. Ten lambs (Santa Inês $\times$ Dorper) aged between four and five months, and with a mean weight of $25.9 \pm 2.8 \mathrm{~kg}$, were used. The animals were placed in metabolic cages equipped with a feeder, drinking fountain, and salt shaker, and which had a wooden slatted floor. The treatments consisted of extruded ration with 30R:70C or 70R:30C. Treatments were distributed in a randomised, complete block design, with each treatment being performed twice and with ten replications. The experiment was carried out in two blocked stages. Differences in the means of treatments were evaluated by Tukey's test at a significance level of 5\%. Intake and digestibility of dry matter and nutrients, water intake by animals, and nitrogen balance were also analysed. The 30R:70C treatment resulted in a lower intake of dry matter, crude protein, neutral detergent fibre, acid detergent fibre and hemicellulose, and caused higher dry matter and neutral detergent fibre digestibility. The 30R:70C treatment also resulted in a lower intake and faecal excretion of nitrogen, consequently establishing a higher ratio between retained and ingested nitrogen. In conclusion, the ration with 30R:70C results in lower intake, and better utilisation of nutrients by the animal.
\end{abstract}

Key words: Apparent digestibility. Dry matter intake. Extrusion. Nutrition. Ovis aries.

\section{Resumo}

Objetivou-se comparar o consumo e digestibilidade da matéria seca e dos nutrientes, e o balanço de nitrogênio de cordeiros alimentados com ração extrusada em diferentes relações volumoso (V):concentrado (C). O experimento foi realizado na Universidade Federal de Uberlândia (UFU), Fazenda Experimental Capim Branco, no período de 07 de dezembro de 2016 a 06 de janeiro de 2017.

1 Discentes, Curso de Doutorado, Programa de Pós-Graduação em Ciências Veterinárias, Universidade Federal de Uberlândia, UFU, Uberlândia, MG, Brasil. E-mail: karla.alves.oliveira@hotmail.com; carolina.am@hotmail.com; tamires.manejo@gmail.com

2 Prof. Dr., Universidade Federal de Uberlândia, UFU, Faculdade de Medicina Veterinária, Programa de Pós-Graduação em Ciências Veterinárias, Uberlândia, MG, Brasil. E-mail: gilbertomacedojr@gmail.com

3 Pesquisadora, M.e em Produção Animal, UFU, Uberlândia, MG, Brasil. E-mail: laura_ferrari@ymail.com

4 Discente, Curso de Zootecnia, UFU, Uberlândia, MG, Brasil. E-mail: marcotulio.s.siqueira@gmail.com

5 Prof. Dr., Departamento de Zootecnia da Escola de Medicina Veterinária e Zootecnia, Universidade Federal de Tocantins, UFT, Araguaína, TO, Brasil. E-mail: luciano.sousa@mail.uft.edu.br

* Author for correspondence 
Foram utilizados 10 cordeiros, mestiços (Santa Inês x Dorper), com idade entre quatro e cinco meses, e peso médio de 25,9 $\pm 2,8 \mathrm{~kg}$. Os animais foram alocados em gaiolas metabólicas providas de comedouro, bebedouro, saleiro e piso ripado de madeira. Os tratamentos consistiam de ração extrusada nas relações 30V:70C e 70V:30C, distribuídos em delineamento em blocos casualizados com dois tratamentos e dez repetições por tratamento. $\mathrm{O}$ experimento foi feito em duas fases blocadas. As médias dos tratamentos foram avaliadas pelo teste de Tukey ao nível de significância de 5\%. Foram analisados o consumo e digestibilidade da matéria seca e dos nutrientes, o consumo de água pelos animais e o balanço de nitrogênio. $\mathrm{O}$ tratamento $30 \mathrm{~V}: 70 \mathrm{C}$ apresentou menor consumo de matéria seca, de proteína bruta, fibra em detergente neutro, fibra em detergente ácido e hemicelulose, e apresentou maior digestibilidade da matéria seca e da fibra em detergente neutro. Apresentou menor consumo e excreção fecal de nitrogênio, consequentemente estabelecendo maior relação entre nitrogênio retido e nitrogênio ingerido. A ração extrusada com relação 30V:70C proporciona menor consumo e melhor aproveitamento dos nutrientes pelo animal.

Palavras-chave: Consumo de matéria seca. Digestibilidade aparente. Extrusão. Nutrição. Ovis aries.

\section{Introduction}

Nutrition is fundamental for the survival, maintenance, and development of all living things. In animals, it is important that nutrition is adequate and balanced, in order to meet their nutritional requirements for maintenance and production.

To ensure that an animal receives a quality feed that meets its requirements, it is necessary to study the intake and digestibility of food. These factors have a high correlation with dry matter intake and with efficiency in the absorption and utilisation of nutrients (ZANINE; MACEDO JÚNIOR, 2006), and are thus important in determining feed quality.

In ruminants, of the nutrients required for maintenance, growth and/ or production, energy (mainly in the form of cellulose and hemicellulose) is the main contributor. Therefore, to fully evaluate the nutritional value of food, it is necessary to consider its bromatological composition along with the effects of intake, digestion, absorption, and metabolism of the animal (LEITE, 2013).

The ingredients of diets, as well as their respective digestibilities, are very important factors in the determination and regulation of dry matter intake. The intake of high-fibre diets is controlled by physical factors such as ruminal filling and digestion rate (CONRAD et al., 1984; MERTENS, 1987), whereas the consumption of diets with high levels of concentrate (high energy density) is controlled by the energy demands of the animal and by metabolic factors (VAN SOEST, 1994). One way to ensure that an animal receives the amount of nutrients necessary to achieve the nutritional requirements of its category, and reach its expected productivity, is by the definition of an adequate roughage to concentrate ratio in its diet.

To increase the efficiency of a diet, one can use ration processing, for example, food extrusion. The extrusion process changes raw materials through a combination of heat, humidity and pressure, and modifies the intake and digestibility characteristics of nutrients (e.g. starch, proteins and fibres). Andrigueto et al. (1981) have stated that extrusion improves the palatability of rations, which, together with its ease of uptake, can reduce dry matter intake. As extrusion is a process that involves high temperatures and short processing times, nutrient loss is reduced; cooking also improves product digestibility due to protein denaturation and starch gelatinisation.

The objective of this work was to compare the effect of two roughage to concentrate ratios (30R:70C and 70R:30C) in extruded feed, on the intake and dry matter digestibility of nutrients by growing lambs. 


\section{Material and Methods}

The experiment was carried out at the Federal University of Uberlândia (UFU), Experimental Farm Capim Branco, in the city of Uberlândia, Minas Gerais. The experimental period was from 7 December 2016 to 6 January 2017. The experimental protocol of this study was approved by the Ethics Committee on Animal Use (ECAU) of UFU under number 139/16.

Ten crossbred lambs (Santa Inês $\times$ Dorper) aged between four and five months and with initial mean weights of $25.9 \pm 2.8 \mathrm{~kg}$ were used in this study. All animals were weighed and dewormed with Levamisole and Monepantel on the first day of the experiment. They were then placed in metabolic cages that were equipped with a feeder, drinker, and salt shaker, and that had a slatted floor and a structure to separate and collect faeces and urine. The cages were located in a masonry shed.

The experimental diet was composed of extruded ration suitable for growing lambs, with roughage and concentrate in the same pellet. The fibrous part of the ration was composed of forage from the genus Urochloa, and the concentrate was composed of corn bran, bran soy, starch, minerals and monensin. Treatments were divided according to the roughage to concentrate ratio of the diet, these being $70 \%$ roughage and $30 \%$ concentrate $(70 \mathrm{R}: 30 \mathrm{C})$ or $30 \%$ roughage and $70 \%$ concentrate $(30 \mathrm{R}: 70 \mathrm{C})$. The bromatological composition of each treatment is shown in Table 1.

Table 1. Bromatological composition of treatments.

\begin{tabular}{lcc}
\hline Nutrient & $70 \mathrm{R}: 30 \mathrm{C}$ & $30 \mathrm{R}: 70 \mathrm{C}$ \\
\hline Dry Matter (DM) $^{*}$ & $92.07 \%$ & $92.05 \%$ \\
\hline Mineral Matter (MM) $^{*}$ & $4.88 \%$ & $5.06 \%$ \\
Crude Protein (CP) $^{*}$ & $10.82 \%$ & $13.64 \%$ \\
Neutral Detergent Fibre (NDF) $^{*}$ & $34.48 \%$ & $29.64 \%$ \\
Acid Detergent Fibre (ADF) $^{*}$ & $20.63 \%$ & $16.41 \%$ \\
Non-Fibrous Carbohydrate (NFC) $^{*}$ & $47.60 \%$ & $49.57 \%$ \\
Ethereal Extract (EE) $^{* *}$ & $2.09 \%$ & $2.21 \%$ \\
Starch $^{* *}$ & $33.84 \%$ & $39.36 \%$ \\
Monensin $^{* *}$ & $17.04 \mathrm{mg} \mathrm{kg}-1$ & $39.76 \mathrm{mg} \mathrm{kg}-1$ \\
\hline
\end{tabular}

* Values obtained after analysis in the animal nutrition laboratory of the Animal Science course of the Federal University of Uberlândia and in partnership with the Federal Institute of the Triângulo Mineiro - Uberaba campus; ** Data provided by the manufacturer.

The experiment was divided in two phases of fifteen days each. Within each phase the first ten days were used for the adaptation of the animals to the diets, and in the remaining five days leftovers (food and water), faeces and urine were collected for the evaluation of treatment digestibility. At the end of the first 15-day phase, the animals were changed between treatments, and a second phase of adaptation and data collection was carried out. The animals were weighed at the beginning and end of each collection period in order to calculate food intake in relation to body weight and average weight.

The extruded ration was given twice a day, at $08 \mathrm{~h} 00$ and $16 \mathrm{~h} 00$, and was weighed immediately before being supplied using a five gram precision scale. Leftovers were measured, and whenever this value was equal to zero, the quantity of ration supplied was increased until a surplus equivalent to $10 \%$ of the offered food was reached. The 
calculation of dry matter intake (DMI) was obtained by calculating the difference in offered to leftover food.

Faeces in the natural matter were weighed daily using a five gram precision scale. The faecal score was also evaluated, according to the scale proposed by Gomes (2008): (1) the faeces are dry and lacking glow; (2) the stool is normal; (3) the stools are slightly softened; (4) the faeces are softened, misshapen and glued together (grape cluster); (5) the faeces are softened and unformed (swine faeces); and (6) the stools are diarrhoeal.

Samples of leftovers and faeces were collected daily and homogenized to create a composite sample. These composite samples were stored in horizontal freezers at $-15{ }^{\circ} \mathrm{C}$ until further analysis. Subsequently, the samples were pre-dried in a forced circulation oven at $55^{\circ} \mathrm{C}$ for 72 hours. The samples were then ground in a Willey-type mill with $1 \mathrm{~mm}$ particles. The contents of the samples were measured as follows: dry matter of leftover and faeces samples at $105{ }^{\circ} \mathrm{C}$ for 24 hours; crude protein (CP), according to the methodology described in protocol 954.01 of the AOAC (1990); mineral matter (MM) according to the methodology described in protocol 942.05 of the AOAC (1990); neutral detergent fibre (NDF), acid detergent fibre (ADF), and ash corrected neutral detergent fibre (NDFac) according to methodology described by Van Soest et al. (1991). The crude protein intake (CPI), neutral detergent fibre intake (NDFI), acid detergent fibre intake (ADFI) and dry matter intake (DMI) were calculated using the difference between offered and leftover rations. The hemicellulose intake (HEMI) was calculated using the difference between ADFI and NDFI. From these chemical analyses it was possible to calculate the final dry matter intake, contents, and apparent digestibility of the nutrients using the formulas proposed by Maynard et al. (1984).

Water intake was calculated based on the difference between the volume of offered and leftover water. Each day a standard quantity of six litres of water was offered to each animal, and more water was given when necessary. An additional bucket of water was used to control for evaporation during each 24 hour period; six litres were added to this bucket each day, and then the next day the remaining water was measured. The amount of water that evaporated from this control bucket was deducted from the water consumption of each animal.

Total urine was collected using plastic buckets, covered with screens to avoid contamination with hairs, rations and faeces, and placed below the metabolism cages. $100 \mathrm{~mL}$ of $2 \mathrm{~N}$ sulphuric acid $\left(\mathrm{H}_{2} \mathrm{SO}_{4}\right)$ was added to each bucket to avoid the volatilization of nitrogen $(\mathrm{N})$ as well as possible microbial fermentation in the environment. Urine collection was performed daily, in the morning. Total urine volume was measured using a graduated test tube (plastic) with $20 \mathrm{~mL}$ precision, and urine density was determined through a Megabrix ${ }^{\circledR}$ manual refractometer. In each experimental period, samples representing $20 \%$ of the total urine collected were deposited in a plastic bottle, duly identified by animal, and stored in a freezer at $-15^{\circ} \mathrm{C}$ for further analysis. The $\mathrm{N}$ content of the urine was calculated by the Kjeldahl method (SILVA; QUEIROZ, 2002).

The balance of $\mathrm{N}$, or nitrogen retained (NR), was obtained using the formula: NR (in grams) $=[(\mathrm{N}$ provided - $\mathrm{N}$ of the leftovers) - ( $\mathrm{N}$ in the faeces $+\mathrm{N}$ in the urine)] as described by Zeoula et al. (2006). Subsequently, the N intake (NI) and the relationship between $\mathrm{N}$ retained and $\mathrm{N}$ ingested (NRET/ NING) were calculated using the formulas: NI (in grams) = $\mathrm{N}$ provided - $\mathrm{N}$ of the leftovers, and NRET/ NING $=\mathrm{NR} / \mathrm{NI}$.

The experiment comprised a randomised block design with two treatments and ten replications per treatment, and was carried out in two blocked stages. The means of each treatment were evaluated by Tukey's test at a significance level of 5\%. Faecal score means were evaluated by the Kruskal and 
Wallis (1952) non-parametric test. For all variables, the normality and homogeneity of the data were tested.

\section{Results and Discussion}

This study found that animals fed the extruded ration with lower fibre content (30R:70C) had lower dry matter intake (DMI) as a percentage of body weight and metabolic weight, and higher dry matter digestibility (DMD, Table 2). The mean DMI was $1.10 \mathrm{~kg} \mathrm{day}^{-1}$, which is within National Research Council (NRC) recommendations for the animal category analysed (1.0-1.3 $\mathrm{kg} \mathrm{day}^{-1}$ (NRC, 2007)). The DMI value in relation to body weight (DMI\% BW) recommended by the NRC (2007) is 3.51\%, so the values found in this study were $4.84 \%$ and $23.36 \%$ higher than recommended values, for the 30R:70C and 70R:30C treatments respectively.

Table 2. Effect of roughage:concentrate ratio on dry matter intake (DMI) expressed in $\mathrm{kg} \mathrm{day}^{-1}$, in relation to body weight $(\% \mathrm{BW})$, metabolic weight $\left(\mathrm{BW}^{0.75}\right)$, and dry matter digestibility $(\mathrm{DMD}, \%)$ in sheep.

\begin{tabular}{|c|c|c|c|c|}
\hline & \multicolumn{2}{|c|}{ Roughage:Concentrate Ratio } & \multirow{2}{*}{ Mean } & \multirow{2}{*}{$\mathrm{CV}(\%)$} \\
\hline & 30R:70C & 70R:30C & & \\
\hline DMI (kg day $\left.{ }^{-1}\right)$ & $1.001 \mathrm{~B}$ & $1.212 \mathrm{~A}$ & 1.100 & 9.330 \\
\hline DMI (\%BW) & $3.68 \mathrm{~B}$ & $4.33 \mathrm{~A}$ & 4.01 & 9.46 \\
\hline $\mathrm{DMI}\left(\mathrm{BW}^{0.75}\right)$ & $84.04 \mathrm{~B}$ & $99.65 \mathrm{~A}$ & 91.85 & 8.34 \\
\hline DMD & $73.58 \mathrm{~A}$ & $61.14 \mathrm{~B}$ & 67.36 & 9.84 \\
\hline
\end{tabular}

CV: coefficient of variation. Different letters $(A, B)$ indicate values that differ by Tukey's Test at $5 \%$ significance.

DMI can be metabolically regulated according to the energy requirements of the animal. When a diet does not have sufficient neutral detergent fibre (NDF) to limit consumption physically, dry matter intake is regulated to meet the metabolic requirement of energy. That is, if a diet has higher amounts of energy and protein than are required for maintenance and production, physiological mechanisms can act to depress appetite and consequently reduce the consumption of food (OLIVEIRA et al., 2017). This may explain the lower DMI observed in the animals that received the diet containing the higher content of concentrate.

Another important metabolic mechanism in DMI regulation is the control of osmotic pressure within the rumen (SUAREZ, 2014). The passage of carbohydrates (monosaccharides or disaccharides) into cells occurs through active transport, that is, it occurs with energy expenditure and against the concentration gradient (KOZLOSKI, 2011). More concentrated diets have a higher particle density, and the higher the concentration of solutes, the higher the osmotic pressure required to maintain solutes inside the cell. As a result, there is a greater exposure of the dietary matrix to the microorganisms of the rumen, which accelerates fermentation, increases digestibility and reduces DMI.

Furthermore, it is possible to explain the difference in DMI of the study animals according to the fermentative characteristics of fibrous and non-fibrous carbohydrates. The ration used for both treatments had fibre particles of $2 \mathrm{~mm}$; this provides a greater capacity of fermentation in the rumen. However, the composition of the treatments was different, in that the 70R:30C treatment contained a greater amount of fibrous carbohydrates. The fermentation of fibrous carbohydrates, particularly cellulose and hemicellulose, is slower because they are more complex structures, thus, animals fed the 70R:30C ration would have had to increase their 
consumption to meet their nutritional requirements. In contrast, as the 30R:70C treatment had a greater amount of concentrate, and consequently of starch (a structure that is rapidly fermented in the rumen), the DMI of animals in this treatment was reduced. The higher the amount of concentrate in the diet, the higher the digestibility of its nutrients - because concentrated foods contain a lower amount of neutral detergent fibre (NDF) and a higher amount of non-fibrous carbohydrates (NFC), the latter being more rapidly fermented in the rumen (CABRAL et al., 2006). Therefore, a lower DMI would be needed to meet the nutritional requirements of animals fed ration that was high in concentrate.

The granulometry of feed influences its rate of passage and ruminal fermentation. Diets finely ground or with a high content of concentrate have a higher density of particles and a high degree of fermentation. Therefore they remain in the most liquid strata of the rumen, where they disappear in the ruminal stratification because of their high fermentability (OLIVEIRA et al., 2013). In this case, the lower retention time of the digesta and the higher digestibility of the nutrients results in an increased production of volatile fatty acids. In diets with digestibility values lower than $66 \%$, food intake is determined by physical factors related to the physical distention of the rumen-reticulum. However, in diets with digestibility values greater than $66 \%$, food intake is controlled by physiological factors - such as the energy or nutritional balance of the diet (CONRAD et al., 1964; MERTENS, 1994).

In support of this theory, animals fed the extruded ration with $70 \%$ concentrate had a DMD of greater than $73 \%$ when metabolic regulation of food intake occurred, with the DMD of the 30R:70C treatment being approximately $17 \%$ higher than the DMD of the 70R:30C treatment. Henrique et al. (2003) found an average DMD of $71.8 \%$ using a diet with $80 \%$ concentrate (corn bran meal, soybean meal and pelleted citrus pulp) for growing crossbred lambs. In contrast, the animals fed the extruded ration containing $70 \%$ roughage presented a DMD value of approximately $61 \%$. Since the particle size of the ration was reduced, there is no ruminal filling effect, however, the composition of the ration was higher in fibrous carbohydrates in relation to nonfibrous carbohydrates (Table 1). This can explain the necessity of a higher DMI to meet the nutritional requirements of the animals fed the 70R:30C diet.

Ustuner et al. (2012) worked with extruded concentrate (corn, barley, sunflower meal, soybean, wheat, and rice) and alfalfa hay in lambs, and found a DMD of $84.8 \% \pm 0.5$ - higher results than those obtained here.

The higher intake of crude protein (CPI), neutral detergent fibre (NDFI), acid detergent fibre (ADFI), and hemicellulose (HEMI) recorded in the 70R:30C treatment can be explained by dry matter intake also being higher in this treatment (Table 2). The same relationship can be seen in the digestibility of neutral detergent fibre (NDFD), as well as DMD, both of which were higher in the 30R:70C treatment (Table 2).

The CPI recommended by the NRC (2007) is $0.137 \mathrm{~kg} \mathrm{day}^{-1}$ for the animal category analysed in this study, thus, the CPI was 19\% lower than recommended in the 30R:70C treatment and 5\% lower in the 70R:30C treatment. However, it should be noted that the extruded ration contains enough crude protein to meet the requirements of this nutrient (Table 1), and that the NRC (2007) guidelines are based on different climatic conditions and on animals that are genetically different to those used in Brazil. Therefore, the NRC requirements can often be an overestimate for animals used in Brazil.

Regarding NDFI, Mertens (1987) proposed that ruminant animals should maintain an intake of NDF of around $1.2 \%$ of their body weight. Therefore, the study animals consuming the feed with 30R:70C had an NDFI that was only 14\% lower than recommendations, and those consuming the feed with 70R:30C had an NDFI 28\% higher. This difference could be directly related to the amount of fibrous fractions in the compositions of each feed, and to the DMI of each treatment (Table 2). 
The digestibility values of neutral detergent fibre (NDFD) found in this study are less than the value recommended by Valadares Filho (1985) of approximately 50\%. Valadares Filho (1985) explains that diets with high amounts of non-fibrous carbohydrates tend to have greater digestibility than those with high amounts of fibrous carbohydrates. This can be observed in the NDFD averages found in this study, in which the 30R:70C treatment obtained NDFD values that were approximately $28 \%$ higher than values in the $70 \mathrm{R}: 30 \mathrm{C}$ treatment. This superiority can also be explained by associating the proportion of soluble carbohydrates in the 30R:70C treatment (Table 1) to the extrusion process. Extrusion expands the food matrix, making it more digestible and easily fermentable in the rumen. This increases the activity of the ruminal microbiota and therefore increases the overall digestibility of the feed.

In this study, the values of nutrient intake and NDFD can be directly linked to DMI and DMD
(Table 2). Specifically, the higher DMI observed in the treatment with $70 \%$ roughage was associated with a higher CPI, NDFI, CFDA and HEMI and with a lower NDFD. This association can be related to the composition of the 70R:30C ration - it had the largest fibrous fraction (Table 1), thereby providing physical regulation of dry matter intake.

There was no difference found between treatments for: water intake, water consumption in relation to DMI, urine volume, urine density, and faecal score (Table 3). The observed mean for water intake $\left(\mathrm{H}_{2} \mathrm{O}\right.$ I) was 3.40 litres of water per day. Forbes (1968) proposed the following equation for calculating the daily water requirement for sheep through the DMI, $\mathrm{H}_{2} \mathrm{O} \mathrm{I}=3.86 \times \mathrm{DMI}-0.99$. Using the average DMI found across both treatments, it is estimated that the recommended water intake during this study was 3.26 litres per day, and thus, the study animals ingested enough water.

Table 3. Effect of roughage:concentrate ratio on water intake $\left(\mathrm{H}_{2} \mathrm{O} \mathrm{I}\right)$, water intake in relation to dry matter intake $\left(\mathrm{H}_{2} \mathrm{O} \mathrm{I} / \mathrm{DMI}\right)$, urine volume (UV), urine density (UD), dry matter of faeces (DMF), faeces mass in natural matter (FMNM), and faecal score (FE) in sheep.

\begin{tabular}{|c|c|c|c|c|}
\hline & \multicolumn{2}{|c|}{ Roughage:Concentrate Ratio } & \multirow{2}{*}{ Mean } & \multirow{2}{*}{$\mathrm{CV}(\%)$} \\
\hline & 30R:70C & 70R:30C & & \\
\hline $\mathrm{H}_{2} \mathrm{O}$ I $\left(\mathrm{L} \mathrm{day}^{-1}\right)$ & 3.27 & 3.54 & 3.40 & 32.72 \\
\hline $\mathrm{H}_{2} \mathrm{O} \mathrm{I} / \mathrm{DMI}\left(\mathrm{L} \mathrm{kg}^{-1}\right.$ day $\left.^{-1}\right)$ & 3.26 & 2.92 & 3.09 & 32.84 \\
\hline $\mathrm{UV}\left(\mathrm{L}\right.$ day $\left.^{-1}\right)$ & 1.22 & 0.85 & 1.03 & 34.60 \\
\hline $\mathrm{UD}\left(\mathrm{g} \mathrm{mL}^{-1}\right)$ & 1.0159 & 1.0155 & 1.0157 & 1.07 \\
\hline DMF (\%) & $35.48 \mathrm{~B}$ & $39.32 \mathrm{~A}$ & 37.40 & 6.00 \\
\hline FMNM $\left(\mathrm{kg} \mathrm{day}^{-1}\right)$ & $0.748 \mathrm{~B}$ & $1.176 \mathrm{~A}$ & 0.958 & 17.01 \\
\hline $\mathrm{FE}^{*}$ & 2.30 & 2.70 & 2.50 & - \\
\hline
\end{tabular}

* Non-parametric statistics; CV: coefficient of variation. Different letters (A, B) indicate values that differ by Tukey's Test at 5\% significance.

The NRC (2007) established a relationship between the consumption of drinking water and the amount of dry matter ingested for sheep. It states that water consumption should be two to three times higher than the DMI, so according to this recommendation, the $\mathrm{H}_{2} \mathrm{O}$ I of the animals in this experiment was within normal ranges. Water can be obtained by animals from three sources: drinking water, water contained in food, and metabolic water derived from the catabolism of nutrients (ESMINGER et al., 1990). This explains the observation of a higher $\mathrm{H}_{2} \mathrm{O}$ I in relation to DMI when extruded rations are used in lambs. The dry matter of extruded rations is high (Table 1), and this 
necessitates greater intake of water per kilogram of food consumed.

Urine is one form of water loss experienced by animals, and the volume of urine produced can be influenced by the age and size of the animal as well as by external factors such as water intake, excessive heat, and dehydration (CARVALHO, 2008). Reece (2006) recommends that urine excretion should be between $100-400 \mathrm{~mL}$ for every $10 \mathrm{~kg}$ of live weight in sheep. As the final mean weight of the animals in this experiment was $29.6 \pm 2.7 \mathrm{~kg}$, the mean urinary excretion of $1030 \mathrm{~mL}$ day $^{-1}$ was within recommendations. Urine density is defined as the concentration rate of the solution compared to the concentration of an equal volume of water, and is useful when assessing the ability of the kidneys to concentrate and dilute urine. Urine density reflects the action of the renal tubules and collecting ducts on the glomerular filtrate, and therefore, is an indirect measure of renal function (MEYER et al., 1992; ARAÚJO et al., 2009). In the two treatments used here, the values of urinary density remained within the standard of normality for sheep $(1,015$ $1,045 \mathrm{~g} \mathrm{~mL}^{-1}$ ) as described in Carvalho (2008) and Reece (2006). This indicates that the animals in this experiment had adequate hydration and did not experience renal changes.

According to the scale proposed by Gomes (2008) a normal faecal score is 2 , so the values found in this experiment were within normal limits. The evaluation of faecal score (shape and consistency) is an important indicator of changes in the gastrointestinal tract and has implications for the health and performance of animals (FERREIRA et al., 2013). The animals fed the $30 \mathrm{R}: 70 \mathrm{C}$ ration had a lower mass in of natural matter and dry matter in the faeces (Table 3), a result that may be associated with the lower DMI and higher digestibility observed for this treatment (Table 2). This also indicates a greater utilisation of nutrients in this diet. Ferreira et al. (2013) also stated that the presence of fibre in a diet leaves the stool with a firmer consistency, and increases the amount of faeces excreted by the animal - this was observed in the 70R:30C treatment, which also had a higher consumption of NDF, ADF, and hemicellulose fractions, and, consequently, a higher weight of natural matter and dry matter in the faeces.

Nitrogen $(\mathrm{N})$ excretion and intake were higher in the 70R:30C treatment, which also had a lower ratio between $\mathrm{N}$ retained and ingested (Table 4). Concentrated foods cause more fermentable nutrients to be present in the rumen, increasing the production of volatile fatty acids, and requiring a lower intake of nutrients - which explains the lower $\mathrm{N}$ intake in the $70 \%$ concentrate treatment. Geron et al. (2015) investigated the inclusion of concentrate in lamb rations (from 20 to $80 \%$ ), and showed that there is also a drop in $\mathrm{N}$ intake as the content of concentrate in the diet increases.

Table 4. Effect of roughage:concentrate ratio on the excretion of nitrogen $(\mathrm{N})$ in urine (UN) and faeces (FN), nitrogen intake (NI), nitrogen retention (NR), and the relationship between retained $\mathrm{N}$ and ingested N (NRET/ NING).

\begin{tabular}{|c|c|c|c|c|}
\hline & \multicolumn{2}{|c|}{ Roughage:Concentrate Ratio } & \multirow{2}{*}{ Mean } & \multirow{2}{*}{$\mathrm{CV}(\%)$} \\
\hline & 30R:70C & 70R:30C & & \\
\hline $\mathrm{UN}\left(\mathrm{g}_{\text {day }}{ }^{-1}\right)$ & 2.66 & 2.20 & 2.43 & 22.30 \\
\hline $\mathrm{FN}\left(\mathrm{g}_{\text {day }}{ }^{-1}\right)$ & $4.61 \mathrm{~B}$ & $9.39 \mathrm{~A}$ & 7.00 & 18.22 \\
\hline NI $\left(\right.$ g day $\left.^{-1}\right)$ & $17.84 \mathrm{~B}$ & $20.91 \mathrm{~A}$ & 19.38 & 7.69 \\
\hline $\mathrm{NR}\left(\mathrm{g} \mathrm{day}^{-1}\right)$ & 10.75 & 9.97 & 10.34 & 26.22 \\
\hline N RET/ N ING & $0.60 \mathrm{~A}$ & $0.47 \mathrm{~B}$ & 0.53 & 25.39 \\
\hline
\end{tabular}

CV: coefficient of variation. Different letters (A, B) indicate values that differ by Tukey's Test at 5\% significance. 
In this study, the average urinary excretion of $\mathrm{N}$ was approximately $33 \%$ below that found in the literature, ranging from 4.0 to 8.5 grams per day (HENRIQUE et al., 2003; MORENO et al., 2010; BRINGEL et al, 2011; MORGADO et al., 2014). Nitrogen excreted via urine is in the form of urea, which forms in the liver from an excess of $\mathrm{N}$ that has been converted to ammonia in the rumen (VAN SOEST, 1994). As such, excreted $\mathrm{N}$ reflects a potential energy expenditure that has been metabolized but not used. Therefore, a lower concentration of $\mathrm{N}$ in the urine reflects a greater retention of $\mathrm{N}$, indicating that the animal was able to take advantage of much of the protein present in the diet.

The mean value of faecal excretion in the literature ranges from 2.8 to 12.3 grams per day (HENRIQUE et al., 2003; MORENO et al., 2010;
BRINGEL et al., 2011; MORGADO et al., 2014). Medeiros and Marino (2015) explain that there is a form of nitrogen that is associated with the fibrous fraction of food and is probably bound to cell wall polysaccharides through covalent bonds - which explains its low solubility. This low solubility may be the reason for this fraction presenting lower rates of degradation in relation to other protein fractions, that is, the form that is not degraded passes through the digestive tract and is excreted in the faeces. These fractions are defined as Neutral Detergent Insoluble Nitrogen (NDIN) and Acid Detergent Insoluble Nitrogen (ADIN). This may explain the higher faecal excretion of $\mathrm{N}$ observed in the treatment 70R:30C, since this was the treatment with a higher content of fibre in the diet (Table 1), with a higher DMI and lower DMD (Table 2), and with a higher NDFI and lower NDFD (Table 5).

Table 5. Effect of roughage:concentrate ratio on the intake of crude protein (CP), neutral detergent fibre (NDF), acid detergent fibre (ADF), hemicellulose, and crude protein and neutral detergent fibre digestibility.

\begin{tabular}{|c|c|c|c|c|}
\hline & \multicolumn{2}{|c|}{ Roughage:Concentrate Ratio } & \multirow{2}{*}{ Mean } & \multirow{2}{*}{$\mathrm{CV}(\%)$} \\
\hline & 30R:70C & 70R:30C & & \\
\hline CPI & $0.111 \mathrm{~B}$ & $0.130 \mathrm{~A}$ & 0.121 & 7.68 \\
\hline NDFI & $0.288 \mathrm{~B}$ & $0.429 \mathrm{~A}$ & 0.359 & 9.52 \\
\hline NDFI $\% B W$ & $1.05 \mathrm{~B}$ & $1.53 \mathrm{~A}$ & 1.29 & 8.94 \\
\hline ADFI & $0.151 \mathrm{~B}$ & $0.248 \mathrm{~A}$ & 0.199 & 9.90 \\
\hline HEMI & $0.137 \mathrm{~B}$ & $0.181 \mathrm{~A}$ & 0.159 & 11.31 \\
\hline CPD & 63.37 & 56.22 & 59.79 & 15.62 \\
\hline NDFD & $47.54 \mathrm{~A}$ & $34.25 \mathrm{~B}$ & 40.90 & 38.02 \\
\hline
\end{tabular}

CPI: crude protein intake, in $\mathrm{kg} \mathrm{day}^{-1}$; NDFI: neutral detergent fibre intake, in $\mathrm{kg} \mathrm{day}^{-1}$; NDFI\%BW: neutral detergent fibre intake in relation to body weight, in \%; ADFI: acid detergent fibre intake, in $\mathrm{kg} \mathrm{day}^{-1}$; HEMI: hemicellulose intake, in kg day ${ }^{-1}$; CPD: crude protein digestibility, in \%; NDFD: neutral detergent fibre digestibility, in \%; CV: coefficient of variation. Different letters (A, B) indicate values that differ by Tukey's Test at $5 \%$ significance.

A higher ratio between $\mathrm{N}$ retained and $\mathrm{N}$ ingested was observed in the 30R:70C treatment, demonstrating that there was better nutrient utilisation in this treatment; faecal excretion was also lower. This higher use of $\mathrm{N}$ may be characteristic of the composition of the 30R:70C ration (Table 1), in that it presents a higher concentration of non-fibrous carbohydrates that would be able to be associated with the extrusion process; the highest DMD was also observed in this treatment (Table 2).

Moreno et al. (2010) explained that an increase in concentrate content, regardless of the type of roughage, is reflected in a higher nitrogen uptake and retention. This is because while intake and 
digestibility are more related to the proportion of roughage in the diet, nitrogen balance or retained nitrogen is highly influenced by the content of concentrate in the diet. This may explain the higher ratio between retained and ingested found in the 30R:70C treatment.

\section{Conclusions}

The use of extruded feed comprising 30\% roughage and $70 \%$ concentrate results in a lower consumption of feed, a higher digestibility of dry matter and neutral detergent fibre, and a better use of nitrogen.

\section{References}

ANDRIGUETO, J. M.; PERLY, L.; MINARDI, I.; GEMAEL, A.; FLEMMING, J. S.; SOUZA, G. A.; BONA FILHO, A. Nutrição animal: as bases e os fundamentos da nutrição animal. 4. ed. São Paulo: Nobel, 1981. 395 p.

ARAÚJO, P. B.; PEREIRA, D. S.; TEIXEIRA, M. N.; COELHO, M. C. O. C.; ALENCAR, S. P. Urinálise como instrumento auxiliar no diagnóstico de enfermidades em pequenos ruminantes. Medicina Veterinária, Recife, v. 3, n. 2, p. 30-38, 2009.

ASSOCIATION OF OFFICIAL ANALYTICAL CHEMISTS - AOAC. Official methods of analysis of AOAC International. 15 $5^{\text {th }}$ ed. Arlington: AOAC, 1990. $1286 \mathrm{p}$.

BRINGEL, L. M. L.; NEIVA, J. N. M.; ARAÚJO, V. L.; BOMFIM, M. A. D.; RESTLE, J.; FERREIRA, A. C. H.; LÔBO, R. N. B. Consumo, digestibilidade e balanço de nitrogênio em borregos alimentados com torta de dendê em substituição à silagem de capim-elefante. Revista Brasileira de Zootecnia, Piracicaba, v. 40, n. 9, p. 19751983, 2011. DOI: 10.1590/S1516-35982011000900019

CABRAL, L. S.; VALADARES FILHO, S. C.; DETMANN, E.; MALAFAIA, P. A. M.; ZERVOUDAKIS, J. T.; SOUZA, A. L.; VELOSO, R. G.; NUNES, P. M. M. Consumo e digestibilidade dos nutrientes em bovinos alimentados com dietas à base de volumosos tropicais. Revista Brasileira de Zootecnia, Piracicaba, v. 35, n. 6, p. 2406-2412, 2006. DOI: 10.1590/ S1516-35982006000800029

CARVALHO, M. B. Semiologia do sistema urinário. In: FEITOSA, F. L. (Ed.). Semiologia veterinária. 2. ed. São
Paulo: Roca, 2008. p. 389-409.

CONRAD, H. R.; PRATT, A. D.; HIBBS, J. W. Regulation of feed intake in dairy cows. I. Change in importance of physical and physiological factors with increasing digestibility. Journal of Dairy Science, Champaign, v. 47 , n. 1, p. 54-62, 1964. DOI: $10.3168 /$ jds.S0022-0302(84)81320-X

CONRAD, H. R.; WEISS, W. P.; ODWONGO, W. O.; SHOCKEY, W. L. Estimating net energy lactation from components of cell solubles and cell walls. Journal of Dairy Science, Champaign, v. 67, n. 2, p. 427-436, 1984. DOI: $10.3168 / j d s . S 0022-0302(84) 81320-X$

ESMINGER, M. E.; OLDFIELD, J. L.; HEINEMANN, J. J. Feeds and nutrition. $2^{\text {th }}$ ed. Clovis: Esminger Publishing, 1990. $1552 \mathrm{p}$.

FERREIRA, S. F.; GUIMARÃES, T. P.; MOREIRA, K. K. G.; ALVES, V. A.; LEMOS, B. J. M.; SOUZA, F. M. Caracterização fecal de bovinos. Revista Científica Eletrônica de Medicina Veterinária, Garça, v. 11, n. 20, p. 1-22, 2013.

FORBES, J. M. The water intake of ewes. British Journal of Nutrition, Cambridge, v. 22, n. 1, p. 33-43, 1968. DOI: 10.1079/BJN19680006

GERON, L. J. V.; COSTA, F. G.; SANTOS, R. H. E.; GARCIA, J.; TRARUTMANN-MACHADO, R. J.; SILVA, M. I. L.; ZEOULA, L. M.; SILVA, D. A. Balanço de nitrogênio em cordeiros alimentados com rações contendo diferentes teores de concentrado. Semina: Ciências Agrárias, Londrina, v. 36, n. 3, p. 1609-1622, 2015. DOI: 10.5433/1679-0359.2015v36n3p1609

GOMES, S. P. Tamanho de partícula do volumoso e frequência de alimentação sobre aspectos nutricionais $e$ do metabolismo energético em ovinos. 2008. Tese (Doutorado em Zootecnia) - Universidade Federal de Minas Gerais, Belo Horizonte.

HENRIQUE, W.; SAMPAIO, A. A. M. S.; LEME, P. R.; ALLEONI, G. F.; LANNA, D. P. D.; MALHEIROS, E. B. Digestibilidade e balanço de nitrogênio em ovinos alimentados à base de dietas com elevado teor de concentrado e níveis crescentes de polpa cítrica peletizada. Revista Brasileira de Zootecnia, Piracicaba, v. 32 , n. 6 , p. $2007-2015$, 2003. Suplemento 2. DOI: 10.1590/S1516-35982003000800026

KOZLOSKI, G. V. Bioquímica dos ruminantes. 3. ed. Santa Maria: Editora UFSM, 2011. 212 p.

KRUSKAL, W. H.; WALLIS, W. A. Use of ranks in one-criterion variance analysis. Journal of the American Statistical Association, v. 47, n. 260, p. 583-621, 1952. DOI: $10.1080 / 01621459.1952 .10483441$ 
LEITE, D. F. L. Consumo e digestibilidade aparente de dietas com niveis crescentes do subproduto do caju em ovinos. 2013. Dissertação (Mestrado em Produção Animal) - Universidade Federal do Rio Grande do Norte, Macaíba.

MAYNARD, L. A.; LOOSLI, J. K.; HINTZ, H. F.; WARNER, R. G. Nutrição animal. 3. ed. Rio de Janeiro: F. Bastos, 1984. 726 p.

MEDEIROS, S. R.; MARINO, C. T. Proteínas na nutrição de bovinos de corte. In: MEDEIROS, S. R.; GOMES, R. C.; BUNGENSTAB, D. J. (Ed.). Nutrição de bovinos de corte: fundamentos e aplicações. Brasília: EMBRAPA, 2015. p. 27-44.

MERTENS, D. R. Predicting intake and digestibility using mathematical models of ruminal function. Journal of Dairy Science, Champaign, v. 64, n. 5, p. 1548-1558, 1987. DOI: $10.2527 /$ jas $1987.6451548 x$

MERTENS, D. R. Regulation of forage intake. In: FAHEY, G. C. (Ed.). Forage quality, evaluation and utilization. Madison: American Society of Agronomy, 1994. p. 450-493.

MEYER, D. J.; COLES, E. H.; RICH, L. J. Veterinary laboratory medicine: interpretation and diagnosis. $3^{\text {th }}$ ed. Philadelphia: Linda Mills, 1992. 350 p.

MORENO, G. M. B.; SILVA SOBRINHO, A. G.; LEÃO, A. G.; LOUREIRO, C. M. B.; PEREZ, H. L.; ROSSI, R. C. Desempenho, digestibilidade e balanço de nitrogênio em cordeiros alimentados com silagem de milho ou cana-de-açúcar e dois níveis de concentrado. Revista Brasileira de Zootecnia, Piracicaba, v. 39, n. 4, p. 853860, 2010. DOI: 10.1590/S1516-35982010000400022

MORGADO, E. S.; EZEQUIEL, J. M. B.; GALZERANO, L.; SANTOS, V. C. Consumo, digestibilidade e balanço de nitrogênio de cordeiros alimentados com alto teor de amido ou fibra solúvel em detergente neutro associados ao óleo de girassol. Semina: Ciências Agrárias, Londrina, v. 35, n. 1, p. 457-466, 2014. DOI: 10.5433/1679-0359.2014v35n1p457

NATIONAL RESEARCH COUNCIL - NRC. Nutrient requirements of small ruminants: sheep, goats, cervids, and new world camelids. Washington: National Academies Press, 2007. 384 p.

OLIVEIRA, B. C.; CAETANO, G. A. O.; CAETANO JÚNIOR, M. B.; MARTINS, T. R.; OLIVEIRA, C. B. Mecanismos reguladores de consumo em bovinos de corte: fatores físicos, fatores químicos, fatores psicogênicos, ingestão de água. Revista Eletrônica Nutritime, Viçosa, MG, v. 14, n. 4, p. 6066-6075, 2017.
OLIVEIRA, V. S.; SANTANA NETO, J. A.; VALENÇA, R. L. Características químicas e fisiológicas da fermentação ruminal de bovinos em pastejo - revisão de literatura. Revista Científica Eletrônica de Medicina Veterinária, Garça, v. 11, n. 20, p. 1-21, 2013.

REECE, W. O. Função renal nos mamíferos. In: REECE, W. O. (Ed.). Dukes fisiologia dos animais domésticos. 12. ed. Rio de Janeiro: Guanabara Koogan, 2006. p. 68-96.

SILVA, D. J.; QUEIROZ, A. C. Análises de alimentos (métodos químicos e biológicos). 3. ed. Viçosa, MG: Editora UFV, 2002. 235 p.

SUAREZ, S. L. B. Fatores envolvidos no consumo de material seca. 2014. Dissertação (Mestrado em Zootecnia) - Universidade Federal de Viçosa, Viçosa, MG.

USTUNER, H.; DIKMEN, S.; TURKMEN, I. I. Effect of feed processing on the fattening performance and carcass traits of Awassi ram lambs. Asian Journal of Animal and Veterinary Advances, Deira, v. 7, n. 12, p. 1331-1339, 2012. DOI: $10.3923 /$ ajava.2012.1331.1339

VALADARES FILHO, S. C. Digestão total e parcial da matéria seca e carboidratos em bovinos e bubalinos. 1985. Tese (Doutorado em Zootecnia) - Universidade Federal de Viçosa, Viçosa, MG.

VAN SOEST, P. J. Nutritional ecology of the ruminant. $2^{\text {th }}$ ed. Ithaca: Cornell University Press, 1994. 476 p.

VAN SOEST, P. J.; ROBERTSON, J. B.; LEWIS, B. A. Methods for dietary fiber, neutral detergent fiber, and nonstarch polysaccharides in relation to animal nutrition. Journal of Dairy Science, Champaign, v. 74, n. 10 , p. $3583-3597,1991$. DOI: $10.3168 /$ jds.S00220302(91)78551-2

ZANINE, A. M.; MACEDO JÚNIOR, G. L. Importância do consumo da fibra para nutrição de ruminantes. Revista Eletrônica de Veterinária, Andalucia, v. 7, n. 4, p. 1-11, 2006.

ZEOULA, L. M.; FERELI, F.; PRADO, I. N.; GERON, L. J. V.; CALDAS NETO, S. F.; PRADO, O. P. P.; MAEDA, E. M. Digestibilidade e balanço de nitrogênio de rações com diferentes teores de proteína degradável no rúmen e milho moído como fonte de amido em ovinos. Revista Brasileira de Zootecnia, Piracicaba, v. 35, n. 5, p. 21792186, 2006. DOI: $10.1590 /$ S1516-35982006000700039 
